\section{TUGAS DAN WEWENANG PEMERINTAH \\ DALAM MELAKSANAKAN PENGELOLAAN \\ SAMPAH YANG BERWAWASAN LINGKUNGAN \\ MENURUT UNDANG-UNDANG NOMOR 18 \\ TAHUN 2008 TENTANG PENGELOLAAN \\ SAMPAH ${ }^{1}$ \\ Oleh: Claudia Angelika Untu}

\begin{abstract}
ABSTRAK
Penelitian ini dilakukan dengan tujuan untuk mengetahui bagaimana tugas pemerintah dalam melaksanakan pengelolaan sampah yang berwawasan lingkungan menurut UndangUndang Nomor 18 Tahun 2008 Tentang Pengelolaan Sampah dan bagaimana wewenang pemerintah dalam melaksanakan pengelolaan sampah yang berwawasan lingkungan menurut Undang-Undang Nomor 18 Tahun 2008 Tentang Pengelolaan Sampah. Dengan menggunakan metode peneltian yuridis normatif, disimpulkan: 1. Tugas pemerintah dalam melaksanakan pengelolaan sampah yang berwawasan lingkungan ialah menjamin terselenggaranya pengelolaan sampah yang baik dan berwawasan lingkungan. Tugas Pemerintah dan pemerintahan daerah diantaranya menumbuhkembangkan dan meningkatkan kesadaran masyarakat dalam pengelolaan sampah dan melakukan penelitian, pengembangan teknologi pengurangan dan penanganan sampah. 2. Wewenang pemerintah dalam melaksanakan pengelolaan sampah yang berwawasan lingkungan diantaranya menetapkan kebijakan dan strategi nasional pengelolaan sampah dan menetapkan norma, standar, prosedur, dan kriteria pengelolaan sampah. Wewenang pemerintah provinsi ialah menetapkan kebijakan dan strategi dalam pengelolaan sampah sesuai dengan kebijakan Pemerintah dan memfasilitasi kerja sama antardaerah dalam satu provinsi, kemitraan, dan jejaring dalam pengelolaan sampah. Undang-Undang Nomor 18 Tahun 2008 Tentang Pengelolaan Sampah, mengatur mengenai Wewenang Pemerintah Kabupaten/Kota, menyelenggarakan pengelolaan sampah, pemerintahan kabupaten/kota mempunyai
\end{abstract}

\footnotetext{
${ }^{1}$ Artikel Skripsi. Dosen Pembimbing: Godlieb N. Mamahit, SH., M.Hum; Kathleen C. Pontoh, SH., MH

${ }_{2}$ Mahasiswa pada Fakultas Hukum Unsrat, NIM. 16071201686
}

kewenanganmenetapkan kebijakan dan dan strategi pengelolaan sampah berdasarkan kebijakan nasional dan provinsi dan menyelenggarakan pengelolaan sampah skala kabupaten/kota sesuai dengan norma, standar, prosedur, dan kriteria yang ditetapkan oleh Pemerintah serta melakukan pembinaan dan pengawasan kinerja pengelolaan sampah yang dilaksanakan oleh pihak lain.

Kata kunci: Tugas Dan Wewenang, Pemerintah, Pengelolaan Sampah, Berwawasan Lingkungan.

\section{PENDAHULUAN}

\section{A. Latar Belakang}

Menurut Penjelasan atas Undang-Undang nomor 18 tahun 2008 tentang Pengelolaan Sampah. Paradigma pengelolaan sampah yang bertumpu pada pendekatan akhir sudah saatnya ditinggalkan dan diganti dengan paradigma baru pengelolaan sampah. Paradigma baru memandang sampah sebagai sumber daya yang mempunyai nilai ekonomi dan dapat dimanfaatkan, misalnya, untuk energi, kompos, pupuk ataupun untuk bahan baku industri. Pengelolaan sampah dilakukan dengan pendekatan yang komprehensif dari hulu, sejak sebelum dihasilkan suatu produk yang berpotensi menjadi sampah, sampai ke hilir, yaitu pada fase produk sudah digunakan sehingga menjadi sampah, yang kemudian dikembalikan ke media lingkungan secara aman. Pengelolaan sampah dengan paradigma baru tersebut dilakukan dengan kegiatan pengurangan dan penanganan sampah. Pengurangan sampah meliputi kegiatan pembatasan, penggunaan kembali, dan pendauran ulang, sedangkan kegiatan penanganan sampah meliputi pemilahan, pengumpulan, pengangkutan, pengolahan, dan pemrosesan akhir. ${ }^{3}$

Sampah yang merupakan sisa kegiatan sehari-hari manusia dan/atau proses alam yang berbentuk padat, tanpa disadari sudah cukup memprihatinkan. Sampah organik yang membusuk tidak saja menyebarkan bau dan mengundang lalat dan tikus, tetapi juga menghasilkan gas methan yang termasuk gas rumah kaca yang menyebabkan pemanasan global. Sedangkan sampah-sampah plastik yang dibakar sebagai upaya mengurangi tumpukan

\footnotetext{
${ }^{3}$ Penjelasan atas Undang-Undang Nomor 18 Tahun 2008
} tentang Pengelolaan Sampah. 
sampah berakibat menjadi polusi udara dan penipisan lapisan ozon. Dimana lepasnya gas dioksin ke udara dapat menyebabkan berbagai penyakit, misalnya kanker, hepatitis, syaraf, dan berkurangnya imunitas. Apalagi air sampah (lindi/leachete) yang keluar dari sampah organik dapat mencemari air tanah. Hal ini menyebabkan berbagai macam penyakit kulit, diare, muntaber dan pencernaan akibat bakteri serta gangguan kesehatan lainnya. Bahkan hasil studi pada tahun 1990 di Wisconsin, USA, akibat dari sampah yang mencemari lingkungan tersebut menyebabkan kelainan kehamilan tahun 1970-1980 melonjak 4 kali lipat, penderita endometriosis mencapai 5,5 juta, penderita kanker payudara tahun 1980-1987 meningkat 22 persen. $^{4}$

Rata-rata perorang dalam perharinya menghasilkan sampah/limbah sebanyak 2 kilogram. Bayangkan berapa besar volume sampah perhari yang dihasilkan masyarakat di Kota Bandar Lampung saja? Belum lagi gaya hidup masyarakat saat ini yang menghasilkan sampah yang sulit terurai di lingkungan, misalnya gaya hidup menggunakan barangbarang yang terbuat dari plastik atau bahan sintetis lainnya. Sampah yang tidak dapat terurai akan menimbulkan masalah menumpuknya sampah. Untuk itu akan membuka tempat pembuangan sampah (TPA) lain. Membuka TPA baru kadang mengakibatkan konflik horizontal masyarakat sekitar TPA yang menyebabkan kerusakan infrastruktur dari investasi dan masalah hukum bagi masyarakat. Dapat dibayangkan demikian kompleksnya masalah yang ditimbulkan oleh sampah. ${ }^{5}$

Menteri Lingkungan Hidup dan Kehutanan Siti Nurbaya Bakar mengatakan, dari 67 sampai 68 juta ton sampah di Indonesia, pada tahun 2013, sebanyak 14 persennya adalah sampah plastik. Pada tahun 2016 naik menjadi 16 persen, dan tahun 2018 dengan berbagai upaya sampah plastiknya turun 1 persen menjadi 15 persen. Telah dilakukan observasi baik di wilayah pesisir maupun di kawasan Taman Nasional, ternyata sampah plastik di wilayah pantai atau pesisir itu jumlahnya 31 persen dari sampah dan di kawasan Taman

\footnotetext{
${ }^{4}$ http://www.fajarsumatera.co.id/Erina Pane. Bersahabat dengan Sampah. Diakses 8/26/2019 4:59 Wita.

${ }^{5}$ Ibid.
}

Nasional komposisinya ternyata mencapai 60 persen dari sampah. Hal ini ada korelasinya dengan perilaku pengunjung. ${ }^{6}$

Terkait kebijakan dan strategi yang telah dilakukan oleh KLHK, Siti Nurbaya menyampaikan bahwa sampah saat ini harus menjadi sumber daya bukan hanya sekedar menjadi sampah. Arah kebijakan dalam penangan sampah yaitu dengan cara sampahnya dikurangi dan sampahnya ditangani. Targetnya untuk tahun 2025, sampah dikurangi sebanyak 30 persen dari timbunan sampah yang ada secara nasional, yaitu dengan cara membatasi timbunan sampah, melakukan daur ulang sampah atau pemanfatan kembali. Penanganan sampah dengan target 70 persen pada tahun 2025 yakni dengan cara pemilahan, daur ulang, pengangkutan, pengolahan maupun proses akhir. Indikator keberhasilan dari pengurangan sampah yaitu menurunkan munculnya sampah per kapita, menurunkan timbunan sampah pada sumber, juga mengurangi jumlah sampah yang terbuang ke lingkungan. ${ }^{7}$ Untuk menjaga agar peraturanperaturan itu dapat berlangsung terus-menerus dan diterima oleh seluruh anggota masyarakat, aturan hukum yang ada harus sesuai dan tidak boleh bertentangan dengan rasa keadilan masyarakat. Dengan demikian, hukum bertujuan untuk menjamin adanya kepastian hukum dalam masyarakat dan harus bersendikan pada keadilan yaitu rasa keadilan masyarakat. $^{8}$

\section{B. Rumusan Masalah}

1. Bagaimanakah tugas pemerintah dalam melaksanakan pengelolaan sampah yang berwawasan lingkungan menurut Undang-Undang Nomor 18 Tahun 2008 Tentang Pengelolaan Sampah ?

2. Bagaimanakah wewenang pemerintah dalam melaksanakan pengelolaan sampah yang berwawasan lingkungan menurut Undang-Undang Nomor 18 Tahun 2008 Tentang Pengelolaan Sampah?

\footnotetext{
${ }^{6}$ http://www.dpr.go.id/berita. Komisi VII Minta Pemerintah Serius Tangani Persoalan Sampah Plastik. Diakses 8/26/2019 5:32 Wita.

${ }^{7}$ lbid.

${ }^{8}$ Arus Akbar Silondae dan Wirawan B. llyas. Pokok-Pokok Hukum Bisnis. Salemba Empat. Jakarta. 2011. hlm. 3.
} 


\section{METODE PENELITIAN}

Penelitian hukum yang dilakukan dengan cara meneliti bahan pustaka atau data sekunder belaka, dapat dinamakan penelitian hukum normatif atau penelitian hukum kepustakaan (di samping adanya penelitian hukum sosiologis atau empiris yang terutama meneliti data primer). ${ }^{9}$

\section{PEMBAHASAN}

\section{A. Tugas Pemerintahan Dalam Melaksanakan Pengelolaan Sampah Yang Berwawasan Lingkungan}

Memahami kewenangan pemerintah daerah dalam pengelolaan sampah merupakan hal yang sangat penting untuk memahami peluang perubahan yang bisa dilakukan oleh pemerintah daerah untuk memperbaiki celah hukum pengelolaan plastik dan sampah plastik dalam peraturan di level nasional. Pemerintah daerah dapat membuat peraturan dan/atau kebijakan untuk mengelola sampah plastik di daerahnya tanpa harus menunggu adanya peraturan dan/atau kebijakan di level nasional. ${ }^{10}$

Hak bagi setiap orang untuk mendapatkan lingkungan hidup yang baik dan sehat sudah diamanahkan pada Pasal 28 ayat (1) UUD 1945. Amanat tersebut memberikan konsekuensi hukum bahwa pemerintah wajib memberikan pelayanan publik dalam pengelolaan sampah. Pemerintah merupakan pihak yang paling berwenang dan bertanggung jawab dalam pengelolaan sampah, meskipun secara operasional, pengelolaannya dapat bermitra dengan badan usaha. ${ }^{11}$

Undang-Undang Nomor 18 Tahun 2008 Tentang Pengelolaan Sampah, mengatur mengenai tugas pemerintahan dalam melaksanakan pengelolaan sampah yang berwawasan lingkungan. Pasal 5. Pemerintah dan pemerintahan daerah bertugas menjamin

\footnotetext{
${ }^{9}$ Soerjono Soekanto dan Sri Mamudji, Penelitian Hukum Normatif Suatu Tinjauan Singkat, PT Raja Grafindo Persada, Jakarta. 1995, hlm. 13-14.

${ }^{10}$ Margaretha Quina, Fajri Fadhillah, Angela Vania. Kewenangan Pemerintah Daerah dalam Pengelolaan Sampah. hlm. 1. Kertas Kebijakan | Agustus 2019 | Seri Pengelolaan Sampah. ICEL. Diakses 8/26/2019 4:36 Wita.

${ }^{11}$ http://www.fajarsumatera.co.id/Erina Pane. Bersahabat dengan Sampah. Diakses 8/26/2019 4:59 Wita.
}

terselenggaranya pengelolaan sampah yang baik dan berwawasan lingkungan sesuai dengan tujuan sebagaimana dimaksud dalam UndangUndang ini. Pasal 6. Tugas Pemerintah dan pemerintahan daerah sebagaimana dimaksud dalam Pasal 5 terdiri atas:

a. menumbuhkembangkan dan meningkatkan kesadaran masyarakat dalam pengelolaan sampah;

b. melakukan penelitian, pengembangan teknologi pengurangan, dan penanganan sampah;

c. memfasilitasi, mengembangkan, dan melaksanakan upaya pengurangan, penanganan, dan pemanfaatan sampah;

d. melaksanakan pengelolaan sampah dan memfasilitasi penyediaan prasarana dan sarana pengelolaan sampah;

e. mendorong dan memfasilitasi pengembangan manfaat hasil pengolahan sampah;

f. memfasilitasi penerapan teknologi spesifik lokal yang berkembang pada masyarakat setempat untuk mengurangi dan menangani sampah; dan

g. melakukan koordinasi antarlembaga pemerintah, masyarakat, dan dunia usaha agar terdapat keterpaduan dalam pengelolaan sampah.

Penjelasan Pasal 6 huruf (e) Hasil pengolahan sampah, misalnya berupa kompos, pupuk, biogas, potensi energi, dan hasil daur ulang lainnya.

Penjelasan Peraturan Pemerintah Republik Indonesia Nomor 81 Tahun 2012 Tentang Pengelolaan Sampah Rumah Tangga dan Sampah Sejenis Sampah Rumah Tangga, menjelaskan Undang-Undang Nomor 18 Tahun 2008 tentang Pengelolaan Sampah mengamanatkan perlunya perubahan yang mendasar dalam pengelolaan sampah yang selama ini dijalankan. Sesuai dengan Pasal 19 UndangUndang Nomor 18 Tahun 2008 tersebut, pengelolaan sampah dibagi dalam dua kegiatan pokok, yaitu pengurangan sampah dan penanganan sampah. Pasal 20 menguraikan tiga aktivitas utama dalam penyelenggaraan kegiatan pengurangan sampah, yaitu pembatasan timbulan sampah, pendauran ulang sampah, dan pemanfaatan kembali sampah. Ketiga kegiatan tersebut merupakan perwujudan dari prinsip 
pengelolaan sampah yang berwawasan lingkungan yang disebut 3R (reduce, reuse, recycle). Dalam Pasal 22 diuraikan lima aktivitas utama dalam penyelenggaraan kegiatan penanganan sampah yang meliputi pemilahan, pengumpulan, pengangkutan, pengolahan, dan pemrosesan akhir sampah. Kegiatan pengelolaan sampah rumah tangga dan sampah sejenis sampah rumah tangga yang diamanatkan oleh Undang-Undang Nomor 18 Tahun 2008 tersebut bermakna agar pada saatnya nanti seluruh lapisan masyarakat dapat terlayani dan seluruh sampah yang timbul dapat dipilah, dikumpulkan, diangkut, diolah, dan diproses pada tempat pemrosesan akhir.

Dengan ditetapkannya Undang-Undang Nomor 18 Tahun 2008 tentang Pengelolaan Sampah, kebijakan pengelolaan sampah dimulai. Kebijakan pengelolaan sampah yang selama lebih dari tiga dekade hanya bertumpu pada pendekatan kumpul-angkut-buang (end of pipe) dengan mengandalkan keberadaan TPA, diubah dengan pendekatan reduce at source dan resource recycle melalui penerapan $3 R$. Oleh karena itu seluruh lapisan masyarakat diharapkan mengubah pandangan dan memperlakukan sampah sebagai sumber daya alternatif yang sejauh mungkin dimanfaatkan kembali, baik secara langsung, proses daur ulang, maupun proses lainnya. ${ }^{12}$

\section{B. Wewenang Pemerintah Dalam Melaksanakan Pengelolaan Sampah Yang Berwawasan Lingkungan}

Menurut Sri Soemantri, istilah pemerintah berasal dari kata "perintah" yang berarti menyuruh melakukan sesuatu sehingga dapat dikatakan bahwa pemerintah adalah kekuasaan yang memerintah sesuatu negara (daerah negara) atau badan tertinggi yang memerintah suatu negara, seperti kabinet merupakan suatu pemerintah. Istilah pemerintahan diartikan dengan perbuatan (cara, hal urusan dan sebagainya) memerintah.$^{13}$

\footnotetext{
${ }^{12}$ Penjelasan Peraturan Pemerintah Republik Indonesia Nomor 81 Tahun 2012 Tentang Pengelolaan Sampah Rumah Tangga dan Sampah Sejenis Sampah Rumah Tangga.

${ }^{13}$ Pipin Syarifin dan Dedah Jubaedah, Pemerintahan Daerah di Indonesia (Di Lengkapi Undang-Undang No. 32 Tahun 2004), Cetakan 1. Pustaka Setia, Bandung, 2006, hlm. 72.
}

Menurut E. Utrecht, secara etimologis dapat diartikan sebagai "tindakan yang terus-menerus (kontinu) atau kebijaksanaan dengan menggunakan suatu rencana maupun akal (rasio) dan tata cara tertentu untuk mencapai tujuan tertentu yang dikehendaki. ${ }^{14}$

Jika pemerintah tidak memiliki legalitas untuk melakukan suatu tindakan, berarti pemerintah tidak boleh bertindak untuk menanggulangi suatu urusan. Dalam praktik penyelenggaraan negara modern dewasa ini, keadaaan seperti ini tentu saja tidak boleh terjadi karena hal itu akan menimbulkan masalah yang sangat serius bagi kelangsungan hidup (eksistensi) bangsa dan negara. ${ }^{15}$

Undang-Undang Nomor 18 Tahun 2008 Tentang Pengelolaan Sampah, mengatur mengenai wewenang pemerintah. Pasal 7. Dalam penyelenggaraan pengelolaan sampah, Pemerintah mempunyai kewenangan:

a. menetapkan kebijakan dan strategi nasional pengelolaan sampah;

b. menetapkan norma, standar, prosedur, dan kriteria pengelolaan sampah;

c. memfasilitasi dan mengembangkan kerja sama antardaerah, kemitraan, dan jejaring dalam pengelolaan sampah;

d. menyelenggarakan koordinasi, pembinaan, dan pengawasan kinerja pemerintah daerah dalam pengelolaan sampah; dan

e. menetapkan kebijakan penyelesaian perselisihan antardaerah dalam pengelolaan samah.

Negara hukum ialah negara yang susunannya diatur dengan sebaiknya-baiknya dalam undang-undang, sehingga segala kekuasaan dari alat-alat pemerintahannya didasarkan pada hukum. Rakyat tidak boleh melakukan tindakan yang bertentangan dengan hukum. Negara hukum itu ialah negara yang diperintah bukan oleh orang-orang tetapi oleh undang-undang (state not governed by men, but by laws). Oleh karena itu di dalam negara hukum, hak-hak rakyat dijamin sepenuhnya oleh negara dan terhadap negara, sebaliknya kewajiban-kewajiban rakyat harus dipenuhi seluruhnya dengan tunduk dan taat kepada

\footnotetext{
${ }^{14} \mathrm{Ibid}, \mathrm{hlm} .72$

${ }^{15}$ Hotma P. Sibuea, Asas Negara Hukum, Peraturan Kebijakan \& Asas-Asas Umum Pemerintahan Yang Baik, Erlangga, Jakarta. 2010, hlm. 36.
} 
segala peraturan pemerintah dan undangundang negara. ${ }^{16}$

Undang-Undang Nomor 18 Tahun 2008 Tentang Pengelolaan Sampah, mengatur mengenai wewenang pemerintah provinsi. Pasal 8. Dalam menyelenggarakan pengelolaan sampah, pemerintahan provinsi mempunyai kewenangan:

a. menetapkan kebijakan dan strategi dalam pengelolaan sampah sesuai dengan kebijakan Pemerintah;

b. memfasilitasi kerja sama antardaerah dalam satu provinsi, kemitraan, dan jejaring dalam pengelolaan sampah;

c. menyelenggarakan koordinasi, pembinaan, dan pengawasan kinerja kabupaten/kota dalam pengelolaan sampah; dan

d. memfasilitasi penyelesaian perselisihan pengelolaan sampah antarkabupaten/antarkota dalam 1 (satu) provinsi.

Hak yaitu: "kewenangan; kekuasaan untuk melakukan sesuatu karena telah ditentukan oleh undang-undang atau peraturan lain; kekuasaan yang benar untuk menuntut sesuatu atau kekuasaan yang benar atas sesuatu. ${ }^{17}$

Istilah kewenangan sering disebut dengan authority, gezag atau yuridiksi. Kewenangan adalah kekuasaan yang diformalkan baik terhadap segolongan orang tertentu, maupun kekuasaan terhadap sesuatu bidangpemerintahan tertentu secara bulat yang berasal dari kekuasaan legislatif maupun dari kekuasaan pemerintah. Pengertian ini berbeda dengan dengan wewenang yang dikenal juga dengan istilah competence atau bevoegdheid. Wewenang hanya mengenai sesuatu onderdil tertentu atau bidang tertentusaja. Jadi kewenangan merupakan kumpulan dari wewenang-wewenang (rechtsbevoegdhehen). Wewenang ini merupakan kemampuan untuk melakukan suatu tindakan hukum publik, atau secara yuridis, wewenang adalah kemampuan bertindak yang diberikan oleh Undang-Undang yang berlaku untuk melakukan hubunganhubungan hukum. ${ }^{18}$

\footnotetext{
${ }^{16} \mathrm{H}$. Murtir Jeddawi, Negara Hukum Good Governance dan Korupsi di Daerah, Total Media, Yogyakarta, 2011. hlm. 12.

${ }^{17}$ Sudarsono, Kamus Hukum. PT. Rineka Cipta. Jakarta. 2009. hlm. 154.

${ }^{18}$ SF. Marbun. Pokok-Pokok Hukum Administrasi Negara. Liberty. Yogyakarta. 1997. hlm. 154.
}

Hukum bekerja dengan cara mengatur perbuatan seseorang atau hubungan antara orang-orang dalam masyarakat. Untuk keperluan pengaturan tersebut, maka hukum menjabarkan pekerjaannya dalam berbagai fungsinya yaitu:

1. Pembuatan norma-norma, baik yang memberikan peruntukan maupun yang menentukan hubungan antara orang dengan orang;

2. Penyelesaian sengketa-sengketa;

3. Menjamin kelangsungan kehidupan masyarakat, yaitu dalam hal terjadi perubahan-perubahan. ${ }^{19}$

Undang-Undang Nomor 18 Tahun 2008 Tentang Pengelolaan Sampah, mengatur mengenai Wewenang Pemerintah Kabupaten/Kota. Pasal 9 ayat:

(1) Dalam menyelenggarakan pengelolaan sampah, pemerintahan kabupaten/kota mempunyai kewenangan:

a. menetapkan kebijakan dan strategi pengelolaan sampah berdasarkan kebijakan nasional dan provinsi;

b. menyelenggarakan pengelolaan sampah skala kabupaten/kota sesuai dengan norma, standar, prosedur, dan kriteria yang ditetapkan oleh Pemerintah;

c. melakukan pembinaan dan pengawasan kinerja pengelolaan sampah yang dilaksanakan oleh pihak lain;

d. menetapkan lokasi tempat penampungan sementara, tempat pengolahan sampah terpadu, dan/atau tempat pemrosesan akhir sampah;

e. melakukan pemantauan dan evaluasi secara berkala setiap 6 (enam) bulan selama 20 (dua puluh) tahun terhadap tempat pemrosesan akhir sampah dengan sistem pembuangan terbuka yang telah ditutup; dan

f. menyusun dan menyelenggarakan sistem tanggap darurat pengelolaan sampah sesuai dengan kewenangannya.

\footnotetext{
${ }^{19}$ Satjipto Raharjo, Hukum dan Perubahan Sosial Suatu Tinjauan Teoretis Serta Pengalaman-Pengalaman di Indonesia, Cetakan Ketiga Genta Publishing, Yogyakarta, 2009, hlm. 111.
} 
(2) Penetapan lokasi tempat pengolahan sampah terpadu dan tempat pemrosesan akhir sampah sebagaimana dimaksud pada ayat (1) huruf $d$ merupakan bagian dari rencana tata ruang wilayah kabupaten/kota sesuai dengan peraturan perundang-undangan.

(3) Ketentuan lebih lanjut mengenai pedoman penyusunan sistem tanggap darurat sebagaimana dimaksud pada ayat (1) huruf $f$ diatur dengan peraturan menteri.

Pembagian Kewenangan.

Penjelasan Pasal 9 ayat (1) Huruf (b) Penyelenggaraan pengelolaan sampah, antara lain, berupa penyediaan tempat penampungan sampah, alat angkut sampah, tempat penampungan sementara, tempat pengolahan sampah terpadu, dan/atau tempat pemrosesan akhir sampah. Pasal $10 . \quad$ Pembagian kewenangan pemerintahan di bidang pengelolaan sampah dilaksanakan sesuai dengan ketentuan peraturan perundangundangan.

Dari perspektif hubungan struktur kelembagaan pemerintahan implikasi politik dari kewenangan urusan pemerintahan adalah adanya divergensi atau pembagian urusan yang kemudian urusan yang dibagi ini menjadi kewenangan dari setiap struktur pemerintahan. Filosofi yang mendasari diperlukan adanya pembagian atau pemencaran urusan pemerintahan adalah karena wilayah negara terlalu luas untuk diurus oleh pemerintah pusat saja, oleh karena itu diperlukan desentralisasi dengan pembentukan daerah otonom dan pembagian urusan. Di samping itu dengan pembagian kerja antarberbagai susunan pemerintahan dapat menciptakan sinergi antarlembaga, efisiensi dan efektivitas pelayanan serta partisipasi masyarakat, sehingga ketentraman, ketertiban dan kesejahteraan dapat tercapai. ${ }^{20}$

Dalam rangka menyelenggarakan pengelolaan sampah secara terpadu dan komprehensif, pemenuhan hak dan kewajiban masyarakat, serta tugas dan wewenang Pemerintah dan pemerintahan daerah untuk melaksanakan pelayanan publik, diperlukan payung hukum dalam bentuk undang-undang.

\footnotetext{
${ }^{20}$ J. Kaloh, Mencari Bentuk Otonomi Daerah, Suatu Solusi Dalam Menjawab Kebutuhan Lokal dan Tantangan Global, Cetakan Kedua. PT. Rineka Cipta. Jakarta. 2007, hlm. 168.
}

Pengaturan hukum pengelolaan sampah dalam Undang-Undang ini berdasarkan asas tanggung jawab, asas berkelanjutan, asas manfaat, asas keadilan, asas kesadaran, asas kebersamaan, asas keselamatan, asas keamanan, dan asas nilai ekonomi. ${ }^{21}$

Apabila masyarakat dapat hidup damai, tenteram dan aman maka kehidupan mereka perlu diatur dengan sebaik-baiknya. Mengatur kehidupan masyarakat perlu kaidah-kaidah yang mengikat setiap anggota masyarakat agar tidak terjadi kejahatan dan pelanggaran terhadap ketertiban umum. Dalam hal ini hukum pidana sangat besar artinya bagi kehidupan masyarakat, sebab hukum pidana adalah: hukum yang mengatur tentang kejahatan dan pelanggaran terhadap kepentingan umum dan perbuatan tersebut diancam dengan pidana yang merupakan suatu penderitaan. ${ }^{22}$

Tugas dan wewenang pemerintah dalam melaksanakan pengelolaan sampah yang berwawasan lingkungan sebagaimana diatur dalam Undang-Undang Nomor 18 Tahun 2008 Tentang Pengelolaan Sampah merupakan upaya untuk memberikan kepastian hukum dalam pengelolaan sampah mengenai tanggung jawab dan kewenangan pemerintah, pemerintahan daerah, serta peran masyarakat dan dunia usaha sehingga pengelolaan sampah dapat berjalan secara proporsional, efektif, dan efisien.

\section{PENUTUP}

\section{A. Kesimpulan}

1. Tugas pemerintah dalam melaksanakan pengelolaan sampah yang berwawasan lingkungan ialah menjamin terselenggaranya pengelolaan sampah yang baik dan berwawasan lingkungan. Tugas Pemerintah dan pemerintahan daerah diantaranya menumbuhkembangkan dan meningkatkan kesadaran masyarakat dalam pengelolaan sampah dan melakukan penelitian, pengembangan teknologi pengurangan dan penanganan sampah.

\footnotetext{
${ }^{21}$ Penjelasan atas Undang-Undang Nomor 18 Tahun 2008 Tentang Pengelolaan Sampah.

${ }^{22}$ Sudarsono, Pengantar Ilmu Hukum, Cetakan Kelima, PT. Rineka Cipta, Jakarta, 2007, hlm. 209.
} 
2. Wewenang pemerintah dalam melaksanakan pengelolaan sampah yang berwawasan lingkungan diantaranya menetapkan kebijakan dan strategi nasional pengelolaan sampah dan menetapkan norma, standar, prosedur, dan kriteria pengelolaan sampah. Wewenang pemerintah provinsi ialah menetapkan kebijakan dan strategi dalam pengelolaan sampah sesuai dengan kebijakan Pemerintah dan memfasilitasi kerja sama antardaerah dalam satu provinsi, kemitraan, dan jejaring dalam pengelolaan sampah. Undang-Undang Nomor 18 Tahun 2008 Tentang Pengelolaan Sampah, mengatur mengenai Wewenang Pemerintah Kabupaten/Kota, menyelenggarakan pengelolaan sampah, pemerintahan kabupaten/kota mempunyai kewenanganmenetapkan kebijakan dan dan strategi pengelolaan sampah berdasarkan kebijakan nasional dan provinsi dan

menyelenggarakan pengelolaan sampah skala kabupaten/kota sesuai dengan norma, standar, prosedur, dan kriteria yang ditetapkan oleh Pemerintah serta melakukan pembinaan dan pengawasan kinerja pengelolaan sampah yang dilaksanakan oleh pihak lain.

\section{B. Saran}

1. Tugas pemerintah dalam melaksanakan pengelolaan sampah yang berwawasan lingkungan memerlukan dukungan koordinasi antarlembaga pemerintah, masyarakat, dan dunia usaha agar terdapat keterpaduan dalam pengelolaan sampah.

2. Wewenang pemerintah dalam melaksanakan pengelolaan sampah yang berwawasan lingkungan perlu ditunjang dengan adanya penetapan kebijakan penyelesaian perselisihan antardaerah dalam pengelolaan sampah. Pemerintah daerah perlu memfasilitasi penyelesaian perselisihan pengelolaan sampah antarkabupaten/antarkota dalam 1 (satu) provinsi dan menyusun dan menyelenggarakan sistem tanggap darurat pengelolaan sampah sesuai dengan kewenangannya.

\section{DAFTAR PUSTAKA}

Hadari Nawawi. Pengawasan Melekat di Lingkungan Aparatur Pemerintah. Gelora Aksara Pratama, Jakarta. 1992.

Hariri Muhwan Wawan. Pengantar Ilmu Hukum, Cet. 1. CV. Pustaka Setia Bandung. 2012.

Hardjasoemantri Koesnadi, Hukum Tata Lingkungan, Edisi Kedelapan, Cetakan Kedelapanbelas, Gajah Mada University Press, Yogyakarta, 2005.

Husni Lalu, Pengantar Hukum Ketenagakerjaan Indonesia, Edisi Revisi, PT. RajaGrafindo, Jakarta, 2008.

Jeddawi Murtir H., Negara Hukum Good Governance dan Korupsi di Daerah, Total Media, Yogyakarta, 2011.

Kaloh J., Mencari Bentuk Otonomi Daerah, Suatu Solusi Dalam Menjawab Kebutuhan Lokal dan Tantangan Global, Cetakan Kedua. PT. Rineka Cipta. Jakarta. 2007.

Mahmud Marzuki Peter, Penelitian Hukum, Edisi Pertama Cetakan ke-2, Kencana Prenada Media Group, Jakarta, 2006.

Marbun Rocky, Deni Bram, Yuliasara Isnaeni dan Nusya A., Kamus Hukum Lengkap (Mencakup Istilah Hukum \& Perundang-Undangan Terbaru, Cetakan Pertama, Visimedia, Jakarta. 2012.

Marbun SF.. Pokok-Pokok Hukum Administrasi Negara. Liberty. Yogyakarta. 1997.

Masriani Tiena Yulies. Pengantar Hukum Indonesia, Cetakan Kelima, Sinar Grafika, Jakarta. 2009.

Muhamad Erwin, Hukum Lingkungan Dalam Sistem Kebijaksanaan Pembangunan Lingkungan Hidup, Cetakan Kedua. PT. Refika Aditama, April 2009.

Nuh Muhammad. Etika Profesi Hukum. CV. Pustaka Setia. Bandung. 2011.

Raharjo Satjipto, Hukum dan Perubahan Sosial Suatu Tinjauan Teoretis Serta Pengalaman-Pengalaman di Indonesia, Cetakan Ketiga Genta Publishing, Yogyakarta, 2009.

Rahardjo Satjipto, Ilmu Hukum, Cetakan ke- IV, PT. Citra Aditya Bakti, Bandung, 2006. 
Sadjijono. Polri Dalam Perkembangan Hukum Di Indonesia, (Editor) M. Khoidin, LaksBang PRESSindo, Yogyakarta. 2008.

Sastrawijaya Tresna, Pencemaran Lingkungan, Cet. 2. Rineka Cipta, Jakarta, 2009.

Sibuea P. Hotma, Asas Negara Hukum, Peraturan Kebijakan \& Asas-Asas Umum Pemerintahan Yang Baik, Erlangga, Jakarta. 2010.

Silondae Akbar Arus dan Wirawan B. Ilyas. Pokok-Pokok Hukum Bisnis. Salemba Empat. Jakarta. 2011.

Sarwoto. Dasar-dasar Organisasi dan Manajemen, Ghalia Indonesia. Jakarta. 1994.

Soekanto Soerjono dan Sri Mamudji, Penelitian Hukum Normatif Suatu Tinjauan Singkat, PT Raja Grafindo Persada, Jakarta. 1995.

Soekanto Soerjono, Pengantar Penelitian Hukum, UI Press, Jakarta, 2005.

Sudarsono, Kamus Hukum. PT. Rineka Cipta. Jakarta. 2009.

Sudarsono, Pengantar IImu Hukum, Cetakan Kelima, PT. Rineka Cipta, Jakarta, 2007.

Sunarso Siswanto, Hukum Pidana Lingkungan Hidup Dan Strategi Penyelesaian Sengketa, PT. Cetakan Pertama, Rineka Cipta, Jakarta, Agustus 2005.

Supriadi dan Alimudin, Hukum Perikanan Indonesia, Cetakan Pertama, Sinar Grafika, Jakarta, 2011.

Syafiie Inu Kencana H., Pengantar IImu Pemerintahan, Cetakan Ketujuh, PT. Refika Aditama. 2011.

Syarifin Pipin dan Dedah Jubaedah, Pemerintahan Daerah di Indonesia (Di Lengkapi Undang-Undang No. 32 Tahun 2004), Cetakan 1. Pustaka Setia, Bandung, 2006.

Thontowi Jawahir. Pengantar Ilmu Hukum. Pustaka Fahima. Yogjakarta. 2007.

Tutik Triwulan Titik, Pengantar Hukum Perdata di Indonesia, Cetakan Pertama, Jakarta, 2006.

Usman, Aspek-Aspek Hukum Perbankan di Indonesia. Penerbit Gramedia Pustaka Utama. Jakarta. 2001.

Quina Margaretha, Fajri Fadhillah, Angela Vania. Kewenangan Pemerintah
Daerah dalam Pengelolaan Sampah. Kertas Kebijakan | Agustus 2019 | Seri Pengelolaan Sampah. ICEL. Diakses 8/26/2019 4:36 Wita.

\section{INTERNET}

http://www.fajarsumatera.co.id/Erina Pane. Bersahabat dengan Sampah. Diakses 8/26/2019 4:59 Wita.

http://www.dpr.go.id/berita. Komisi VII Minta Pemerintah Serius Tangani Persoalan Sampah Plastik. Diakses 8/26/2019 5:32 Wita.

https://www.hukumonline.com/Sovia Hasanah.Cara Pemerintah Mengelola Sampah. Diakses 8/26/2019 4:40 Wita. 